\title{
Prevalence and Risk Factors of Smoking, and Tobacco use among Secondary School Boy Students in Tabuk Region, Saudi Arabia
}

\author{
Tawfik M. Ghabrah, MBBS, MPH, PhD \\ Department of Family and Community Medicine, \\ Faculty of Medicine, King Abdulaziz University \\ Jeddah, Saudi Arabia \\ tghabrah@hotmail.com
}

\begin{abstract}
As tobacco epidemic continues to increase among adolescents, tobacco control programs based on actual field studies are crucially needed. A cross-sectional study was conducted in Tabuk region to determine the prevalence and risk factors of tobacco use among secondary school boy students. A three-stage stratified random sampling design was used to recruit a sample of 1,680 students from 15 secondary schools. A self-administrated Arabic questionnaire was used to collect the required data. A descriptive and analytic statistical analysis $\mathrm{w}$ as done. Overall prevalence of cigarette and shisha smoking was $25.7 \%$ and $25.9 \%$, respectively. Prevalence of current daily and non-daily smokers was $16.3 \%$ and $9.4 \%$, respectively. Prevalence of shisha smokers was $4.3 \%$ and $21.6 \%$ on regular and non-regular basis, respectively. Odds ratios of important risk factors were: Nationality (1.42), fathers' smoking (1.42), mothers' smoking (2.74), school absenteeism (2.96), sleep disturbance (2.26), and mothers' living status (1.80). Important reasons for smoking were entertainment $(43.2 \%)$, overcoming the feeling of oppression $(36.1 \%)$ and peer pressure $(11.0 \%)$. The majority of students $(70.5 \%)$ addressed the desire for quitting smoking for health promotion $(48.9 \%)$; Islamic rules $(25.5 \%)$ and family dislike $(19.9 \%)$ reasons. In conclusion, a quarter of the high school students were smokers which necessitate an urgent intervention.
\end{abstract}

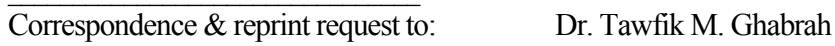

P.O. Box 80215, Jeddah 21589, Saudi Arabia

Accepted for publication: 01 December 2013. Received: 22 October 2013. 
Keywords: Smoking, Tobacco use, Shisha, Prevalence, Risk factors, Tabuk, Saudi Arabia.

\section{Introduction}

Tobacco use is one of the leading preventable causes of premature death, disease and disability around the world ${ }^{[1]}$. Currently, approximately 5.4 million people die each year due to tobacco-related illnesses - a figure expected to increase to more than 8 million a year by $2030^{[2]}$. Globally, $14 \%$ of all non-communicable deaths among adults are attributable to tobacco ${ }^{[3]}$.

As global patterns in tobacco use change, it has been estimated that over the next two decades, $70 \%$ of tobacco deaths will be in developing countries ${ }^{[4,5]}$. About $80 \%$ of the world's smokers now live in low and middle income countries, at least in part due to the lack of adequate tobacco control programs ${ }^{[6]}$. The recent trend in tobacco prevention activities is to target and intensify the tobacco control measures in the youth ${ }^{[7]}$.

The Global Youth Tobacco Survey (GYTS) is targeting the population group of 13- to 15-years-old and analyses the data yearly ${ }^{[8]}$. The global data indicated that $12 \%$ of boys and $6 \%$ of girls are current smokers ${ }^{[9,10]}$.

Gulf Cooperation Council (GCC) Countries have a prevalence of $14.4 \%$ to $23.9 \%$ of ever smokers and $14.3 \%$ to $21.1 \%$ current smokers among school children. It is interesting to note that shisha smoking is common in GCC and used even more than cigarettes as few studies indicated $^{[11]}$.

There is anecdotal evidence that consumption of tobacco in Saudi Arabia has increased in recent years. This has been attributed to improving economic conditions, higher incomes and exposure to smoking lifestyle behaviors in the media ${ }^{[12]}$. The overall prevalence of smoking among the Saudi population ranges from 2.4 to $52.9 \%$ with a median of $17.5 \%{ }^{[13]}$. The variability of the overall prevalence has been assessed to a certain extent in the youth by utilizing the GYTS $^{[14]}$. The Saudi GYTS was conducted in 2010 and results revealed that $14.9 \%$ of students currently use any form of tobacco, 
$8.9 \%$ currently smoke cigarettes, $11.0 \%$ currently use some other form of tobacco, and $9.5 \%$ currently smoke shisha ${ }^{[15]}$.

To the best of the investigator's knowledge, a study on the smoking habits of boys attending secondary schools in Tabuk region, Saudi Arabia using GYTS is lacking. The study objectives were to determine the prevalence level of cigarette and shisha smoking among the secondary school boy students in Tabuk region; to describe the main risk factors of smoking, and to identify the reasons and pattern of tobacco use of the study subjects.

\section{Materials and Methods}

\section{Research Setting}

Tabuk is one of the provinces of Saudi Arabia, located on the Northwest part of the country. The region is composed of 6 governorates and has a surface area of $108,000 \mathrm{~km}^{2}$ with a population size of 791,535 (2010). Its capital is Tabuk city and it has 103 boys secondary schools enrolling 31,418 students in $2012^{[16,17]}$.

\section{Study Design}

A cross-sectional analytic survey (point prevalence) has been chosen as a suitable method to investigate the current research problem.

\section{Target Population}

The target population was the secondary school male students enrolled in 103 schools in Tabuk region. Out of these, 15 schools were randomly chosen from Tabuk city and 5 other towns (Taimaa, Haqel, Duba, Alwajh and Umlujj).

\section{Sample Design}

The calculation of the sample size was based on the assumption of a margin of error at $5 \%$, a confidence interval of $95 \%$, and a prevalence of smoking among teenagers $=21 \%$ which was obtained from a study conducted in three regions of Saudi Arabia ${ }^{(18)}$. 
The calculated sample size was 560 students (minimum sample size), but the investigator has decided to enlarge the sample size to ensure an adequate geographical coverage of Tabuk region, especially for remote governorates that have certain demographic and cultural characteristics and to overcome any problem regarding response rate. However, the investigator has adequately considered the proportional allocation of the original sample size. Therefore, a sample of 120 students from each randomly chosen school was necessary for the survey i.e., the total sample size was 1,680 students recruited from 15 different secondary boy's schools.

The multi-stage random sampling technique has been utilized to recruit the required students. At the first stage, Tabuk city and the 5 towns (Taimaa, Haqel, Duba, Alwajh and Umlujj) have been chosen as the strata for the random sampling technique. During the second stage, 15 secondary schools have been randomly chosen by the simple random sampling technique from all towns. At the third stage, classes were chosen by the simple random sampling technique, and thereafter, the students were selected by the systematic random sampling technique. All students in the selected classes were eligible to participate.

\section{Defining Dependant Variables}

The Nominal Group Technique (NGT) has been utilized in order to define working and practical definitions for the main independent variables of tobacco smoking status (ever smoker, current daily smoker and current non-daily smoker) for cigarettes smokers and also for shisha smokers (regular and non-regular) that suite the current research problem and the target subjects. The subject who answered the question of "have you ever smoked?" was defined as ever cigarette smoker. A current daily smoker is defined as a student who smoked one cigarette at least per day in last 30 days. A current nondaily smoker is defined as a person smoked more than one day in last 30 days but not on a daily basis.

Regular shisha smoker has been defined as a student who smokes shisha at least once per week and on a regular basis, meanwhile, the non-regular shisha smoker has been defined as an occasional shisha 
smoker and not on a regular basis. The experts of NGT were 4 professors of community medicine, 3 professors of chest diseases, 2 professors of behavior medicine and 2 doctors from the Saudi Ministry of Health who are working in pulmonary health care programs.

\section{Measuring Tobacco Prevalence}

The author has utilized the following definitions proposed by the Global Tobacco Surveillance ${ }^{[19]}$ and adapted by the current study (NGT) experts: Current cigarette smokers (percentage of respondents who currently smoke cigarettes); current daily cigarette smokers (percentage of respondents who currently smoke cigarettes daily); and current non-daily cigarette smokers (percentage of respondents who currently smoke tobacco but not daily).

\section{Data Collection Tool and Technique}

A self-administrated Arabic questionnaire which is a modified version of the global youth tobacco survey questionnaire was used as the main data collection tool. It contained a set of closed ended questions; in addition to very few open ended questions that have been coded after the conduction of pilot study. The students were asked to fill out all the questions after explaining the objectives and usefulness of the research. To avoid revealing uncomfortable information, the name or other identifying features of the subject were not asked and this was stressed in the instructions given prior to the completion of the questionnaire.

\section{Pretest Study}

It has been carried out during the preparatory research phase $\left(1^{\text {st }}\right.$ and $2^{\text {nd }}$ months) in order to: Formulate the research problem for more precise investigation, refine the study variables, and test the validity (internal and external) and reliability of the study tools and instruments. 


\section{Ethical Approval and Consent}

Ethical approval was obtained from the Research and Ethics Committee of Tabuk Medical College. Consent from students was obtained after explaining the study contents in details and confirming the confidentiality in handling and storing the survey data.

\section{Statistical Analysis}

The collected data have been analyzed using SPSS statistical package version 20. Descriptive and analytic statistics were performed including chi-squared test and Pearson's contingency coefficient (PCC). Risk assessment based on odds ratio analysis has been performed. Level of significance was set at $\mathrm{P}$ value of $<0.05$ throughout.

\section{Results}

Table 1 shows the main socio-economic and demographic characteristics of the studied students and their parents. The highest mean age (years) was of the current daily smokers (18.5 \pm 1.52$)$. Low educational levels have been observed among the students' fathers and mothers, and only $16.4 \%$ of fathers and $14.5 \%$ of mothers were university graduates or have postgraduate studies. Statistically significant differences regarding mothers' education have been noticed between cigarette smokers' groups and non-ever smoking group $(\mathrm{P}=0.01)$. The main occupations of the students' fathers were military (48.1\%) and non-professional jobs (21.0\%); meanwhile, most of the students' mothers were housewives (82.2\%). Statistically significant differences regarding fathers' occupation have been were observed in Haqel and Taimaa governorates, respectively.

Table 2 shows that the overall prevalence of current cigarette smokers is $25.7 \%$, current daily smokers is $16.3 \%$ and current nondaily smokers is $9.4 \%$. The highest $(35.8 \%)$ and lowest $(15.5 \%)$ prevalence rates of current smokers were observed in Haqel and Taimaa governorate, respectively. In addition, the highest $(24.1 \%)$ and lowest $(9.3 \%)$ prevalence rates of current daily smokers were found in Haqel and Taimaa governorates, respectively. Moreover, the highest $(11.7 \%)$ and lowest $(6.2 \%)$ prevalence rates of non-daily 
Table 1. Important demographic characteristics of the studied students and their parents in Tabuk region.

\begin{tabular}{|c|c|c|c|c|c|c|c|c|c|c|}
\hline \multirow{3}{*}{$\begin{array}{l}\text { Charac- } \\
\text { teristic }\end{array}$} & \multicolumn{6}{|c|}{ Cigarette Smokers } & \multirow{3}{*}{\multicolumn{2}{|c|}{$\begin{array}{l}\text { Non-Ever Smokers } \\
(\mathrm{N}=399)\end{array}$}} & \multirow{3}{*}{\multicolumn{2}{|c|}{$\begin{array}{c}\text { Total } \\
(\mathrm{N}=1680)\end{array}$}} \\
\hline & \multirow{2}{*}{\multicolumn{2}{|c|}{$\begin{array}{l}\text { Ever Smokers }{ }^{1} \\
\quad(\mathrm{~N}=850)\end{array}$}} & \multicolumn{4}{|c|}{ Current Smokers } & & & & \\
\hline & & & \multicolumn{2}{|c|}{$\begin{array}{c}\text { Daily } \\
(\mathrm{N}=273)\end{array}$} & \multicolumn{2}{|c|}{$\begin{array}{l}\text { Non-Daily } \\
(\mathrm{N}=158)\end{array}$} & & & & \\
\hline $\begin{array}{l}\text { Age (years): } \\
(\mathrm{X} \pm \mathrm{SD})\end{array}$ & \multicolumn{2}{|c|}{$17.9 \pm 1.42$} & \multicolumn{2}{|c|}{$18.5 \pm 1.52$} & \multicolumn{2}{|c|}{$18.0 \pm 1.33$} & \multicolumn{2}{|c|}{$17.7 \pm 1.32$} & \multicolumn{2}{|c|}{$17.8 \pm 1.37$} \\
\hline $\begin{array}{l}\text { Parent } \\
\text { Education: }\end{array}$ & $\begin{array}{l}\text { Father } \\
(\%)^{2}\end{array}$ & $\begin{array}{l}\text { Mother } \\
(\%)^{2}\end{array}$ & $\begin{array}{l}\text { Father } \\
(\%)^{2}\end{array}$ & $\begin{array}{c}\text { Mother } \\
(\%)^{2}\end{array}$ & $\begin{array}{l}\text { Father } \\
(\%)^{2}\end{array}$ & $\begin{array}{l}\text { Mother } \\
(\%)^{2}\end{array}$ & $\begin{array}{l}\text { Father } \\
(\%)^{2}\end{array}$ & $\begin{array}{c}\text { Mother } \\
(\%)^{2}\end{array}$ & $\begin{array}{l}\text { Father } \\
(\%)^{2}\end{array}$ & $\begin{array}{c}\text { Mother } \\
(\%)^{2}\end{array}$ \\
\hline Illiterate & 12.8 & 25.2 & 15.2 & 27.5 & 16.5 & 25.2 & 13.7 & 31.7 & 13.8 & 27.1 \\
\hline $\begin{array}{l}\text { Read and } \\
\text { Write }\end{array}$ & 16.1 & 18.3 & 18.5 & 19.3 & 15.1 & 16.8 & 18.4 & 26.4 & 16.9 & 20.3 \\
\hline $\begin{array}{l}\text { Primary } \\
\text { School }\end{array}$ & 20.4 & 15.8 & 20.0 & 15.2 & 15.1 & 18.7 & 19.0 & 10.9 & 19.5 & 14.8 \\
\hline $\begin{array}{l}\text { Preparatory } \\
\text { School }\end{array}$ & 18.8 & 14.0 & 16.7 & 11.5 & 22.4 & 16.1 & 16.3 & 8.4 & 18.2 & 12.5 \\
\hline $\begin{array}{l}\text { Secondary } \\
\text { School }\end{array}$ & 14.8 & 11.5 & 13.7 & 10.0 & 13.8 & 9.7 & 17.6 & 10.4 & 15.2 & 10.9 \\
\hline $\begin{array}{l}\text { University } \\
\text { Graduates }\end{array}$ & 11.2 & 11.1 & 8.9 & 10.8 & 8.6 & 11.6 & 9.7 & 8.6 & 10.2 & 10.5 \\
\hline $\begin{array}{l}\text { Postgraduate } \\
\text { Studies }\end{array}$ & 6.0 & 4.0 & 7.0 & 5.6 & 8.6 & 1.9 & 5.3 & 3.6 & 6.2 & 4.0 \\
\hline Significance & \multicolumn{10}{|c|}{$\begin{array}{c}\mathrm{X}^{2}=4.56, \mathrm{P}=0.60, \mathrm{PCC}^{3}=0.05 ; \mathrm{X}_{\mathrm{b}}{ }_{\mathrm{b}}=4.00, \mathrm{P}=0.68, \mathrm{PCC}^{3}=0.09 \\
\mathrm{X}^{2}{ }_{\mathrm{c}}=15.10, \mathrm{P}=0.01, \mathrm{PCC}^{3}=0.10 ; \mathrm{X}_{\mathrm{d}}^{2}=4.01, \mathrm{P}=0.54, \mathrm{PCC}^{3}=0.09\end{array}$} \\
\hline \multicolumn{11}{|l|}{$\begin{array}{l}\text { Parent } \\
\text { Occupation: }\end{array}$} \\
\hline $\begin{array}{l}\text { Professional } \\
\text { jobs }\end{array}$ & 13.6 & 11.6 & 11.1 & 11.6 & 8.0 & 9.8 & 16.1 & 9.5 & 13.2 & 10.8 \\
\hline $\begin{array}{l}\text { Non- } \\
\text { Professional } \\
\text { jobs }\end{array}$ & 21.1 & 3.1 & 18.4 & 3.4 & 23.8 & 2.6 & 21.3 & 2.8 & 21.0 & 3.1 \\
\hline Military & 50.1 & - & 48.3 & - & 43.1 & - & 45.5 & - & 48.1 & - \\
\hline Traders & 10.3 & - & 14.6 & - & 18.5 & - & 8.7 & - & 11.4 & - \\
\hline Laborers & 3.6 & - & 4.6 & - & 4.0 & - & 3.8 & - & 3.8 & - \\
\hline Housewife & NA & 83.2 & NA & 82.8 & NA & 85.0 & NA & 84.4 & NA & 82.2 \\
\hline Others & 1.4 & 2.2 & 3.1 & 2.3 & 2.7 & 2.6 & 4.6 & 3.3 & 2.5 & 4.0 \\
\hline Significance & \multicolumn{10}{|c|}{$\begin{array}{c}\mathrm{X}_{\mathrm{a}}^{2}=28, \mathrm{P}=0.0001, \mathrm{PCC}^{3}=0.13 ; \mathrm{X}_{\mathrm{b}}^{2}=5.99, \mathrm{P}=0.42, \mathrm{PCC}^{3}=0.12 \\
\mathrm{X}_{\mathrm{c}}^{2}=1.82, \mathrm{P}=0.61, \mathrm{PCC}^{2}=0.33 ; \mathrm{X}_{\mathrm{d}}^{2}=0.58, \mathrm{P}=0.90, \mathrm{PCC}^{3}=0.04\end{array}$} \\
\hline
\end{tabular}

Ever Smokers ${ }^{1}$ (excluding current smokers); $(\%)^{2}$ Valid Percent; $X_{a}^{2}$, between Current Smokers and Non-ever Smokers in relation to Fathers' Education/Occupation; $X^{2}{ }_{b}$ between the Current Daily Smokers and Non-daily Smokers in relation to Fathers' Education/Occupation; $X_{c}^{2}$, between Current Smokers and Non-ever Smokers in relation to Mothers' Education/Occupation; $X^{2}{ }_{d}$ between the Current Daily Smokers and Non-daily Smokers in relation to Mothers' Education/Occupation; PCC ${ }^{3}$, Pearson's Contingency Coefficient; NA, Not Applicable.

smokers were observed in Haqel and Taimaa governorates, respectively.

Table 3 illustrates that the prevalence rates of regular, non-regular and overall shisha smokers were $4.3 \%, 21.6 \%$ and $25.9 \%$, respectively. The distribution of current regular smokers and current non-regular smokers by city or town was statistically significant $(\mathrm{P}=$ 0.046). 


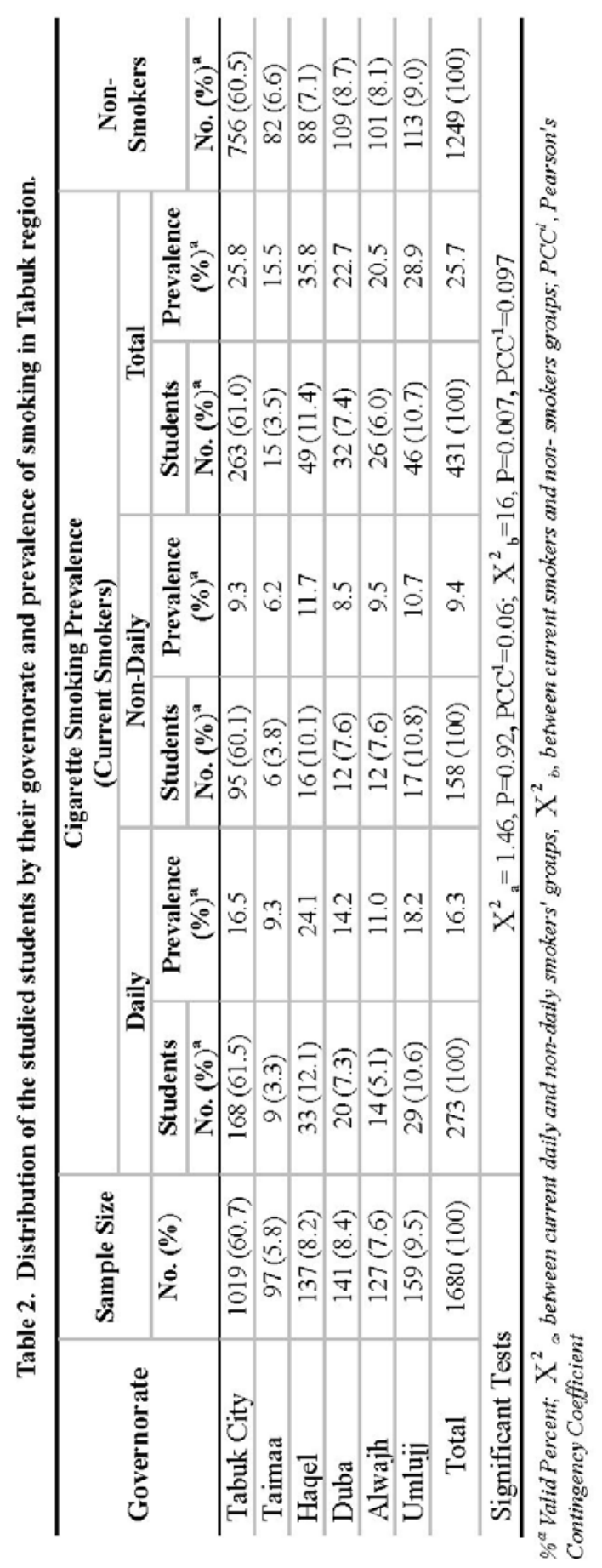




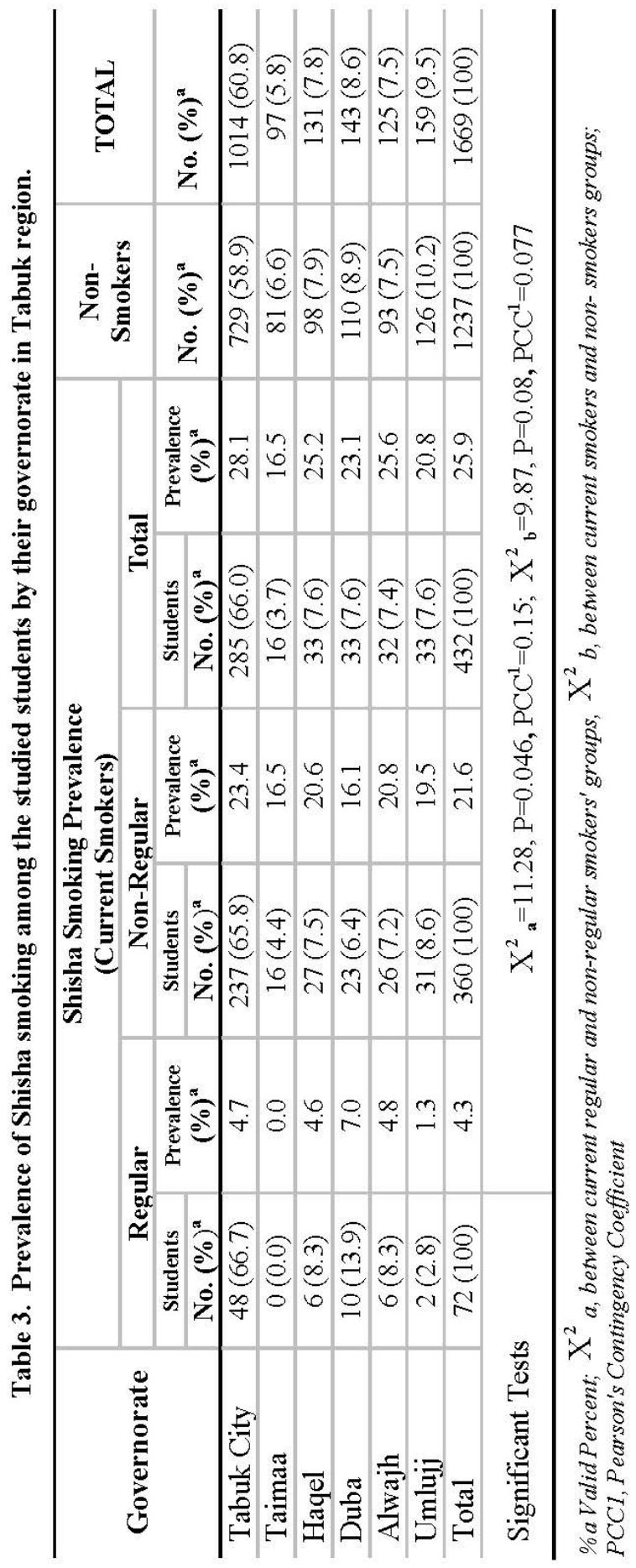


Table 4 shows results for risk assessment of important risk factors. The following risk factors were associated with the smoking status of the current smokers groups (daily and non-daily) with their corresponding odds ratios (OR) and confidence intervals (CI): Nationality (Saudi or non-Saudi) (OR=1.57, CI: 0.59-4.14), mothers' smoking status (smoker or non-smoker) $(\mathrm{OR}=1.16, \mathrm{CI}$ : 0.34-3.92), school absenteeism (OR=1.40, CI: 0.91-2.15), and mothers' living status (alive or deceased) (OR=2.32, CI: 0.51-10.49).

In addition, Table 4 demonstrates that the following risk factors were associated with the current smokers and non-smokers' groups with their corresponding odds ratios (OR) and confidence intervals (CI): nationality (Saudi or non-Saudi) $(\mathrm{OR}=1.42, \mathrm{CI}: 0.83-2.45)$, fathers' smoking status (smoker or non-smoker) $(\mathrm{OR}=1.42$, CI: 1.112.80), mothers' smoking status (smoker or non-smoker) $(\mathrm{OR}=2.74$, CI: 1.24-6.05), school absenteeism (OR=2.96 CI: 2.33-3.76), sleep disturbance $(\mathrm{OR}=2.26, \mathrm{CI}: 1.72-2.96)$, and mothers' living status (alive or deceased) $(\mathrm{OR}=1.80, \mathrm{CI}: 0.79-4.07)$.

As shown in Table 5, the main smoking reasons were entertainment $(43.2 \%)$ and overcoming a feeling of oppression $(36.1 \%)$. The difference in the distribution among the smokers' groups (ever, daily and non-daily smokers) by their governorates was statistically significant $(\mathrm{P}<0.0001)$.

Table 6 shows that the mean age at initiation of cigarette smoking was $14.5 \pm 2.53$ years. Immediate and usual morning wake up smoking was high (56.0\%) among the daily smokers compared with the non-daily smokers $(10.1 \%)$. The average number of cigarettes per day was $13.0 \pm 8.10$ (daily smokers) and $5.8 \pm 7.13$ (non-daily smokers). Meanwhile, the usual places of smoking were the public areas $(56.2 \%)$ and home $(26.5 \%)$. About $70 \%$ of smokers have 


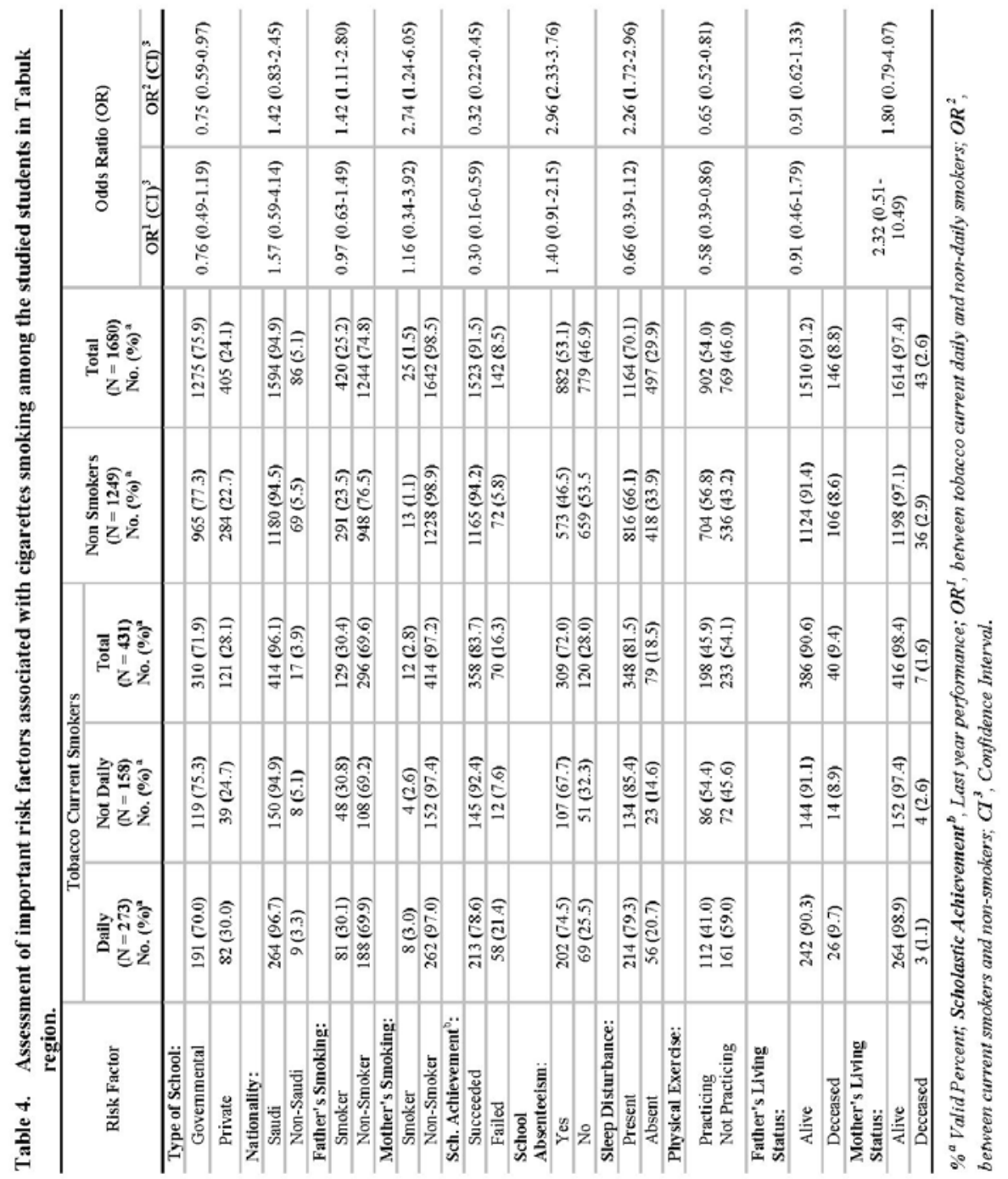


Table 5. Distribution of smoking reasons among the studied students' smokers in Tabuk region.

\begin{tabular}{|c|c|c|c|c|c|c|c|c|}
\hline \multirow{3}{*}{ Smoking Reasons } & \multicolumn{6}{|c|}{ Smoking Status } & \multirow{2}{*}{\multicolumn{2}{|c|}{$\begin{array}{c}\text { Total } \\
(\mathrm{N}=\mathbf{1 2 8 1})^{1}\end{array}$}} \\
\hline & \multicolumn{2}{|c|}{$\begin{array}{l}\text { Ever Smokers } \\
\qquad(\mathrm{N}=\mathbf{8 5 0})^{1}\end{array}$} & \multicolumn{2}{|c|}{$\begin{array}{l}\text { Daily Smokers } \\
\qquad(N=273)^{1}\end{array}$} & \multicolumn{2}{|c|}{$\begin{array}{c}\text { Non-Daily } \\
\text { Smokers } \\
(\mathrm{N}=158)^{1} \\
\end{array}$} & & \\
\hline & $F^{2}(\%)$ & $\mathbf{R O}^{3}$ & $F^{2}(\%)$ & RO $_{3}$ & $F^{2}(\%)$ & $\mathbf{R O}^{3}$ & $F^{2}(\%)$ & $\mathbf{R O}^{3}$ \\
\hline For entertainment & $\begin{array}{c}342 \\
(44.5) \\
\end{array}$ & $1^{\mathrm{st}}$ & $\begin{array}{c}104 \\
(35.0) \\
\end{array}$ & $2^{\text {nd }}$ & $\begin{array}{c}88 \\
(51.8) \\
\end{array}$ & $1^{\mathrm{st}}$ & $\begin{array}{c}534 \\
(43.2) \\
\end{array}$ & $1^{\mathrm{st}}$ \\
\hline $\begin{array}{l}\text { Overcome } \\
\text { oppression feeling }\end{array}$ & $\begin{array}{c}250 \\
(32.5) \\
\end{array}$ & $2^{\text {nd }}$ & $\begin{array}{c}145 \\
(48.8) \\
\end{array}$ & $1^{\text {st }}$ & $\begin{array}{c}51 \\
(30.0) \\
\end{array}$ & $2^{\text {nd }}$ & $\begin{array}{c}446 \\
(36.1) \\
\end{array}$ & $2^{\text {nd }}$ \\
\hline Peer pressure & $\begin{array}{c}95 \\
(12.4)\end{array}$ & $3^{\text {rd }}$ & $\begin{array}{c}23 \\
(7.7)\end{array}$ & $3^{\text {rd }}$ & $\begin{array}{c}18 \\
(10.6)\end{array}$ & $3^{\text {rd }}$ & $\begin{array}{c}136 \\
(11.0)\end{array}$ & $3^{\text {rd }}$ \\
\hline Looks like adults & $\begin{array}{c}56 \\
(7.3)\end{array}$ & $4^{\text {th }}$ & $\begin{array}{c}13 \\
(4.4)\end{array}$ & $4^{\text {th }}$ & $\begin{array}{c}10 \\
(5.9)\end{array}$ & $4^{\text {th }}$ & $\begin{array}{c}79 \\
(6.4)\end{array}$ & $4^{\text {th }}$ \\
\hline To be civilized & $\begin{array}{c}26 \\
(3.4)\end{array}$ & $5^{\text {th }}$ & $\begin{array}{c}12 \\
(4.0)\end{array}$ & $5^{\text {th }}$ & $\begin{array}{c}3 \\
(1.8)\end{array}$ & $5^{\text {th }}$ & $\begin{array}{c}41 \\
(3.3)\end{array}$ & $5^{\text {th }}$ \\
\hline Total & $\begin{array}{c}769 \\
(100)\end{array}$ & NA & $\begin{array}{c}297 \\
(100)\end{array}$ & NA & $\begin{array}{c}170 \\
(100)\end{array}$ & NA & $\begin{array}{l}1236 \\
(100)\end{array}$ & NA \\
\hline
\end{tabular}

$\boldsymbol{N}^{1}$, Number of students; $\boldsymbol{F}^{2}$, Frequency, Number of responses (Multiple response questions); $\mathbf{R O}^{3}$, Rank Order, $X^{2}$, among the smokers' groups, NA, Not Applicable; PCC $^{4}$, Pearson's Contingency Coefficient

Table 6. Pattern of cigarette smoking among the studied students in Tabuk region.

\begin{tabular}{|c|c|c|c|c|c|c|}
\hline \multirow{3}{*}{$\begin{array}{c}\text { Pattern } \\
\text { Characteristics }\end{array}$} & \multicolumn{4}{|c|}{ Smoking Status } & \multirow{2}{*}{\multicolumn{2}{|c|}{ Total $(N=431)$}} \\
\hline & \multicolumn{2}{|c|}{ Daily (N=273) } & \multicolumn{2}{|c|}{$\begin{array}{c}\text { Not Daily } \\
(\mathrm{N}=158)\end{array}$} & & \\
\hline & No. & $\%^{1}$ & No. & $\%^{1}$ & No. & $\%^{1}$ \\
\hline \multirow{2}{*}{$\begin{array}{l}\text { Age at starting } \\
\text { smoking (years): } \\
\qquad(X \pm S D)\end{array}$} & \multirow{2}{*}{\multicolumn{2}{|c|}{$14.4 \pm 2.37$}} & \multirow{2}{*}{\multicolumn{2}{|c|}{$14.7 \pm 2.83$}} & & \\
\hline & & & & & \multicolumn{2}{|c|}{$14.5 \pm 2.53$} \\
\hline \multicolumn{7}{|c|}{ Immediate morning wake up smoking: } \\
\hline Usually & 149 & 56.0 & 15 & 10.1 & 164 & 39.5 \\
\hline Sometimes & 74 & 27.8 & 48 & 32.2 & 122 & 29.4 \\
\hline No & 43 & 16.2 & 86 & 57.7 & 129 & 31.1 \\
\hline \multicolumn{7}{|l|}{$\begin{array}{l}\text { Number of cigarettes } \\
\text { per day: }\end{array}$} \\
\hline$\leq 1$ & \multicolumn{2}{|c|}{7} & \multicolumn{2}{|c|}{46} & \multicolumn{2}{|c|}{53} \\
\hline $2-5$ & \multicolumn{2}{|c|}{44} & \multicolumn{2}{|c|}{53} & \multicolumn{2}{|c|}{97} \\
\hline $6-10$ & \multicolumn{2}{|c|}{92} & \multicolumn{2}{|c|}{12} & \multicolumn{2}{|c|}{104} \\
\hline $11-20$ & \multicolumn{2}{|c|}{56} & \multicolumn{2}{|c|}{9} & \multicolumn{2}{|c|}{65} \\
\hline$\geq 20$ & \multicolumn{2}{|c|}{69} & \multicolumn{2}{|c|}{12} & \multicolumn{2}{|c|}{81} \\
\hline$(X \pm S D)$ & \multicolumn{2}{|c|}{$13.0 \pm 8.10$} & \multicolumn{2}{|c|}{$5.8 \pm 7.13$} & & .78 \\
\hline $\begin{array}{l}\text { Tobacco Quitting } \\
\text { Desire: }\end{array}$ & & & & & & \\
\hline Present & 191 & 71.0 & 100 & 69.4 & 291 & 70.5 \\
\hline Absent & 78 & 29.0 & 44 & 30.6 & 122 & 29.5 \\
\hline
\end{tabular}


Table 6. (Continuation)

\begin{tabular}{|c|c|c|c|c|c|c|c|}
\hline \multirow{3}{*}{$\begin{array}{c}\text { Pattern } \\
\text { Characteristics }\end{array}$} & \multicolumn{4}{|c|}{ Smoking Status } & \multirow{2}{*}{\multicolumn{3}{|c|}{ Total $(N=431)$}} \\
\hline & \multicolumn{2}{|c|}{ Daily (N=273) } & \multicolumn{2}{|c|}{$\begin{array}{c}\text { Not Daily } \\
(N=158)\end{array}$} & & & \\
\hline & No. & $\%^{1}$ & No. & $\%^{1}$ & No. & \multicolumn{2}{|c|}{$\%^{1}$} \\
\hline \multicolumn{8}{|l|}{$\begin{array}{l}\text { Tobacco Quitting } \\
\text { Trial: }\end{array}$} \\
\hline Tried & 179 & 66.8 & 88 & 74.0 & 267 & \multicolumn{2}{|c|}{69.0} \\
\hline Did not try & 89 & 33.2 & 31 & 26.0 & 120 & \multicolumn{2}{|c|}{31.0} \\
\hline Usual Smoking Place: & $\mathbf{F}^{2}$ & $\%$ & $\mathbf{F}^{2}$ & $\%$ & $\mathbf{F}^{2}$ & $\%$ & $\begin{array}{l}\text { Rank } \\
\text { Order }\end{array}$ \\
\hline Public areas & 126 & 50.4 & 92 & 66.7 & 218 & 56.2 & $1^{\text {st }}$ \\
\hline Home & 79 & 31.6 & 24 & 17.4 & 103 & 26.5 & $2^{\text {nd }}$ \\
\hline Recreation house & 21 & 8.4 & 13 & 9.4 & 34 & 8.8 & $3^{\text {rd }}$ \\
\hline School & 18 & 7.2 & 7 & 5.1 & 25 & 6.4 & $4^{\text {th }}$ \\
\hline Friend's home & 6 & 2.4 & 2 & 1.5 & 8 & 2.1 & $5^{\text {th }}$ \\
\hline \multicolumn{8}{|l|}{$\begin{array}{l}\text { Tobacco Quitting Trial } \\
\text { Reason: }\end{array}$} \\
\hline Health promotion & 31 & 44.9 & 38 & 52.8 & 69 & 48.9 & $1^{\text {st }}$ \\
\hline $\begin{array}{l}\text { Islamic rules } \\
\text { forbidden it }\end{array}$ & 19 & 27.5 & 17 & 23.6 & 36 & 25.5 & $2^{\text {nd }}$ \\
\hline $\begin{array}{l}\text { My family do not like } \\
\text { it }\end{array}$ & 15 & 21.7 & 13 & 18.1 & 28 & 19.9 & $3^{\text {rd }}$ \\
\hline Peer Pressure & 2 & 2.9 & 3 & 4.2 & 5 & 3.6 & $4^{\text {th }}$ \\
\hline Saving money & 2 & 2.9 & 1 & 1.4 & 3 & 2.1 & $5^{\text {th }}$ \\
\hline
\end{tabular}

expressed their desire to give up smoking. However, $66.8 \%$ of daily smokers have tried to quit compared with $74.0 \%$ of non-daily smokers. Tobacco quitting desire has been addressed by $70.5 \%$ of smokers for health promotion (48.9\%); Islamic rules $(25.5 \%)$ and family dislike $(19.9 \%)$ reasons.

\section{Discussion}

Prevalence of tobacco use among male adolescents varies markedly from country to country, ranging from 2.7 to 65.8 percent among the 157 countries with surveys since $2000^{[20]}$. In this study, the investigator found that the overall prevalence of tobacco smokers among secondary boy school students was $25.7 \%$. This is a comparable figure with other Saudi studies that found the prevalence 
of smokers among school students ranged from 12.0-29.8\% (median $=16.5 \%)^{[13]}$.

Shisha smoking is common among young people in Middle Eastern countries, with prevalence estimates of regular smoking of $11 \%-32 \%{ }^{[21-25]}$, and there is evidence of a recent increase in these prevalence rates ${ }^{[26,27]}$. The prevalence of shisha smokers found in the current study was $4.31 \%$ for regular smokers and $21.57 \%$ for nonregular smokers.

It is evident that the current study reported a comparable high prevalence rates of tobacco smoking as compared with other Saudi studies e.g., Al Nohair ${ }^{[28]}$, Al Ghobain et al. ${ }^{[14]}$, and Jarallah et al. ${ }^{[18]}$. The investigator found only one study conducted in Tabuk city which reported a smoking prevalence of $34 \%$ for male students ${ }^{[29]}$ but it was limited to Tabuk city only and conducted in April, 2005. Therefore, one cannot generalize from its findings to Tabuk region. The differences among the reviewed studies may partly be explained by differences in the definition of smoking status, time factors, sampling and methodological issues, besides the differences in demographic and socio-economic characteristics of the studied regions.

Cigarette and shisha smoking prevalence rates varied among the studied governorates in Tabuk region. The current research found that the prevalence of current cigarette smokers ranged from $15.5 \%$ to $35.8 \%$, meanwhile, the prevalence of current shisha smokers ranged from $16.5 \%$ to $28.1 \%$. The disparities identified here add another layer of data to our knowledge about the importance of epidemiological pattern of tobacco prevalence distribution. These findings addressed the important need for the decision makers to carefully consider the actual tobacco use influencing factors at the program(s) delivery levels.

The high prevalence of tobacco use in Tabuk region can be partly contributed to the insufficient tobacco control programs and the aggressive tobacco industry behavior. In addition, as the current study indicated, more factors could be incriminated, which include: More commonly affected students were with smoking fathers and 
mothers; irregular school attendance; presence of sleep disturbance; and deceased father and/or mother.

The most important identified reasons for smoking were entertainment followed by overcoming feeling of oppression and peer pressure. This would be in line with the fact that, a range of sociodemographic, environmental, behavioral and personal indicators predicts the likelihood of adopting or rejecting smoking, particularly in early adolescence.

This study confirms that the most important age to start smoking was around 15 years $(14.0 \pm 2.53$ years $)$. This should enforce the tobacco controlling decision makers to start their programs about smoking prevention in primary and intermediate schools. The American Cancer Society (ACS) addressed the importance of this finding and stated that nearly all cases of first time tobacco use take place before a person finishes high school; the younger people are when they begin to smoke, the more likely they will become adult smokers ${ }^{[30]}$.

The common place of smoking in the current study was public areas, home and recreation places. Therefore, legislations like restricted sales of tobacco products and ban of smoking in public places might be helpful in reducing the tobacco use among these students.

Indicators of socioeconomic position vary across studies; often education, occupation, and income level are used interchangeably to measure socioeconomic position ${ }^{[31]}$. It is important, however, to examine multiple indicators of socioeconomic position simultaneously if one is to understand their combined impact and thereby, provide more complete descriptions of social inequalities in tobacco use ${ }^{[32]}$. In current study, only $16.4 \%$ of fathers and $14.5 \%$ of mothers have a university degree and/or postgraduate studies. Also, $13.2 \%$ of fathers and $10.8 \%$ of mothers have professional jobs. Many studies have consistently documented a strong socioeconomic gradient in tobacco use, with higher rates of use among those of greater social disadvantage ${ }^{[31.32]}$. In fact, Jarvis and Wardle ${ }^{[33]}$ concluded that any marker of disadvantage that can be envisaged and 
measured, whether personal, material or cultural is likely to have an independent association with cigarette smoking. Recent evidence documents the same socioeconomic tobacco use gradient; tobacco use has been found to be higher among individuals at lower levels of education and with lower standards of living ${ }^{[32-34]}$.

The investigator found that $70.5 \%$ of the studied students had a desire to quit smoking and $69.0 \%$ of them have tried quitting it. This is in accordance with the results of GYTS that showed a very high percentage of students who were current smokers wanted to quit. They also revealed that these students were not receiving adequate support or guidance they needed to quit tobacco ${ }^{[35]}$. The main reasons for trying to quit Tobacco use by the studied students in the current study were health promotion, Islamic rules and family dislike.

In conclusion, the study has provided support of a particularly high prevalence of tobacco use by the secondary school male students in Tabuk region, Saudi Arabia, where the prevalence of smoking is among the highest levels in the country. Hence, there is an urgent need for health decision makers to decrease the prevalence of tobacco use and for regulation of tobacco marketing and selling to minors. Similarly, tobacco preventive programs should consider actual situation of the target population and sites based on scientifically sound research studies. School-based interventions like counseling to promote cessation among current users and tobacco education to prevent initiation are necessary. Enforcement of legislations is essential to reduce the tobacco use among school students. Finally, an efficient and systematic tobacco surveillance system should be developed.

\section{References}

[1] Ezzati M, Lopez AD, Rodgers A, Vander Hoorn S, Murray CJ; Comparative Risk Assessment Collaborating Group. Selected major risk factors and global and regional burden of disease. Lancet 2002; 360(9343): 1347-1360.

[2] Centers for Disease Control and Prevention. Smoking and tobacco use. Accessed 2013. < http://www.cdc.gov/tobacco $>$.

[3] [No authors listed]. WHO Global Report, Mortality Attributable to Tobacco, 2012, Geneva; WHO, 2012. 14. 
[4] Scollo MM, Winstanley MH. Tobacco in Australia: Facts and Issues. Third Edition. Melbourne: Cancer Council Victoria; 2008. Accessed 2013. $<$ http://www.tobaccoinaustralia.org.au $>$.

[5] Hammond SK. Global patterns of nicotine and tobacco consumption. In: Handbook of Experimental Pharmacology 192. JE Henningfield et al. (eds.), Nicitube Psychopharmacology. Berlin Heidleberg: Sprinder-Verlag, 2009. 3-28. Accessed 2013. <http://www.springerlink.com/content/t353k255747342h6>.

[6] [No authors listed]. The World Health Report 1999: Making a Difference. Geneva: WHO, 1999. Accessed 2013. <http://www.who.int/whr/>.

[7] [No authors listed]. Cigarette use among high school students - United States, 19912009. MMWR 2010; 59(26): 797-801.

[8] Ali M, Bassiony M. Smoking in Saudi Arabia. Saudi Med J 2009; 30(10): 1368.

[9] Szilagyi T. Global progress report on the implementation of the WHO Framework Convention on Tobacco Control. WHO 2010. 46. Accessed 2013. $<$ http://www.who.int/fctc/reporting/summaryreport.pdf.>

[10] Al-Bedah AM, Qureshi NA, Al-Guhaimani HI, Basahi JA. The Global Youth Tobacco Survey - 2007. Comparison with the Global Youth Tobacco Survey 20012002 in Saudi Arabia. Saudi Med J 2010; 31(9): 1036-1043.

[11] Moh'd Al-Mulla A, Abdou Helmy S, Al-Lawati J, Al Nasser S, Ali Abdel Rahman S, Almutawa A, Abi Saab B, Al-Bedah AM, Al-Rabeah AM, Ali Bahaj A, El-Awa F, Warren CW, Jones NR, Asma S. Prevalence of tobacco use among students aged 13-15 years in Health Ministers' Council/Gulf Cooperation Council Member States, 2001-2004. J Sch Health 2008; 78(6): 337-343.

[12] Mohamed MK. WHO smoke-free city case study; Tobacco-free cities for smoke-free air: a case study in Mecca and Medina. WHO 2011; 7.

[13] Bassiony M. Smoking in Saudi Arabia. Saudi Med J 2009; 30(7): 876-881.

[14] Al Ghobain MO, Al Moamary MS, Al Shehri SN, Al-Hajjaj MS. Prevalence and characteristics of cigarette smoking among 16 to 18 years old boys and girls in Saudi Arabia. Ann Thorac Med 2011; 6(3): 137-140.

[15] World Health Organization (WHO). Global Youth Tobacco Survey (GYTS), Saudi Arabia (Ages 13-15) Fact Sheet, 2011; 2.

[16] [No authors listed]. Health Statistical Year Book, Department of Statistics, Ministry of Health. Jeddah: MOH. 2010. 36.

[17] El-Anzy A. [Statistical Guide of Schools in Tabuk Region, General Administration of Tabuk Region, Information Management Unit, Ministry of Education, Saudi Arabia] (in Arabic), 2012. 2.

[18] Jarallah JS, al-Rubeaan KA, al-Nuaim AR, al-Ruhaily AA, Kalantan KA. Prevalence and determinants of smoking in three regions of Saudi Arabia. Tob Control 1999; 8(1): 53-56.

[19] Global Tobacco Surveillance System. Tobacco Questions for Surveys: A Subset of Key Questions from the Global Adult Tobacco Survey (GATS), 2nd Edition. Atlanta, GA: Centers for Disease Control and Prevention, 2011; 3.

[20] Pan American Health Organization. Prevalence of tobacco use. Accessed 2013. $<$ http://new.paho.org/hq/index.php?option=com_content\&view=article\&id=4348\&Ite $\operatorname{mid}=2391>$. 
[21] Akl EA, Gunukula SK, Aleem S, Obeid R, Jaoude PA, Honeine R, Irani J. The prevalence of waterpipe tobacco smoking among the general and specific populations: a systematic review. BMC Public Health 2011; 11: 244.

[22] Refaat A. Practice and awareness of health risk behaviour among Egyptian university students. East Mediterr Health J 2004; 10(1-2): 72-81.

[23] Zoughaib SS, Adib SM, Jabbour J. Prevalence and determinants of water pipe or narghile use among students in Beirut's southern suburbs. J Med Liban 2004; 52(3): 142-148.

[24] Tamim H, Terro A, Kassem H, Ghazi A, Khamis TA, Hay MM, Musharrafieh U. Tobacco use by university students, Lebanon, 2001. Addiction 2003; 98(7): 933-939.

[25] Maziak W, Fouad FM, Asfar T, Hammal F, Bachir EM, Rastam S, Eissenberg T, Ward KD. Prevalence and characteristics of narghile smoking among university students in Syria. Int J Tuberc Lung Dis 2004; 8(7): 882-889.

[26] Momenan AA, Etemadi A, Ghanbarian A, Azizi F. The rising prevalence of waterpipe smoking among Iranian adolescents: Tehran Lipid and Glucose Study. The $13^{\text {th }}$ World Conference on Tobacco OR Health. Washington DC, USA. 2006.

[27] Chaaya M, El Roueiheb Z, Chemaitelly H. Azar G, Nasr J, Al-Sahab B. Argileh smoking among university students: a new tobacco epidemic. Nicotine Tob Res 2004; 6(3): 457-463.

[28] Al Nohair S. Prevalence of smoking and its related behaviors and beliefs among secondary school students in Riyadh, Saudi Arabia. Int J Health Sci (Qassim) 2011; 5(1): 51-7.

[29] Abdalla AM, Al-Kaabba AF, Saeed AA, Abdulrahman BM, Raat H. Gender differences in smoking behavior among adolescents in Saudi Arabia. Saudi Med J 2007; 28(7): 1102-1108.

[30] [No authors listed]. Child and teen tobacco use. American Cancer Society. Accessed 2013.

$<$ http://www.cancer.org/cancer/cancercauses/tobaccocancer/childandteentobaccouse/ch ild-and-teen-tobacco-use-child-and-teen-tobacco-use>.

[31] Bobak M, Jha P, Nguyen S, Jarvis M. Poverty and smoking, In: Tobacco Control in Developing Countries. Jha P, Chaloupka FJ, eds.New York, NY: Oxford Uni P, 2000. 41-61.

[32] Sorensen G, Gupta PC, Pednekar MS. Social disparities in tobacco use in Mumbai, India: the roles of occupation, education, and gender. Am J Public Health 2005; 95(6): 1003-1008.

[33] Jarvis MJ, Wardle J. Social patterning of individual health behaviors: the case of cigarette smoking. In: Social Determinants of Health. Marmot M, Wilkinson RG, eds. Oxford, England: Oxford Uni P, 1999. 240-255.

[34] Gupta PC. Socio-demographic characteristics of tobacco use among 99,598 individuals in Bombay, India, using hand-held computers. Tob Control 1996; 5(2): 114-120.

[35] [No authors listed]. Regional Strategy for Utilization of Global Youth Tobacco Survey Data, Regional Office for South-East Asia. WHO 2005; 11. 


\title{
معدل الانتشار و عوامل الخطورة للتدخين و استخدام التبغ \\ بين طلاب المدارس الثانوية بمنطقة تبوك في المملكة العربية السعودية
}

\author{
توفيق محمد علي غبره

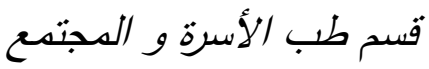 \\ كلية الطب، جامعة الدلك عبدالعزيز \\ جلة - المدلكة العربية السعودية
}

الهستخل. كلما استمر وباء التخخين في الازبياد بين الرراهقين

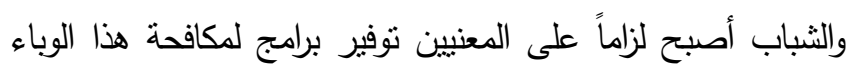

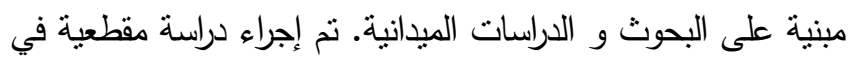

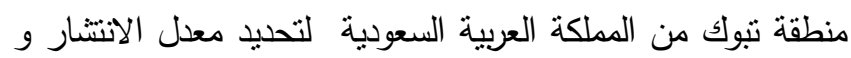
عوامل الخطورة للتنخين بين طلاب الدارس الثانوية، و نلك باستخدام

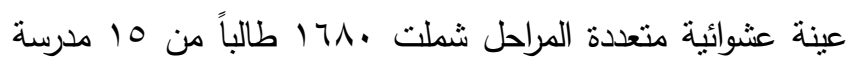

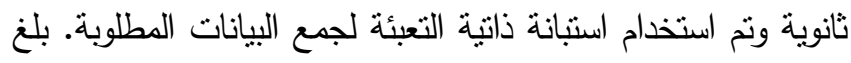

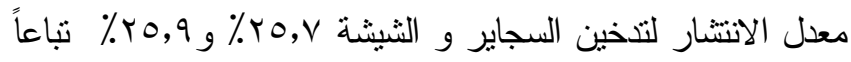

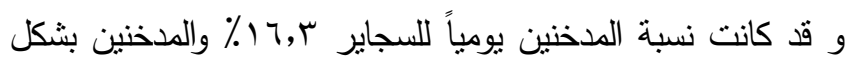
منظظم اللشيشة ץ, ؟ ٪. أظهرت ننائج التحليل الإحصائي الخاصة بمعامل الخطورة أن العوامل المهمة المرتبطة بالتخين شملت التالي

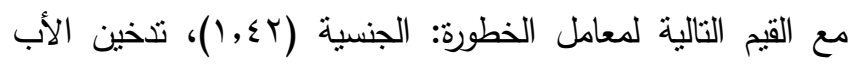

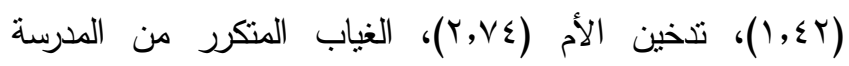

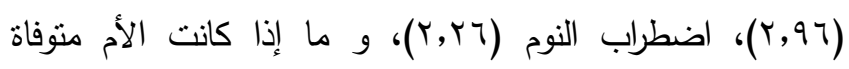




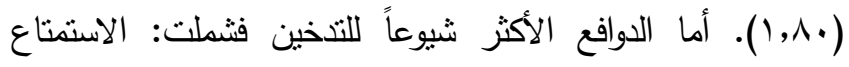

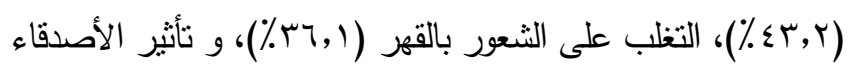

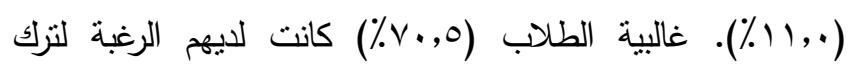

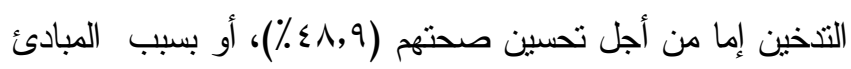

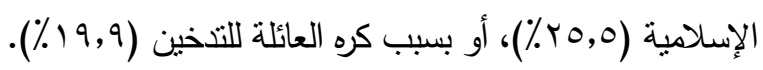

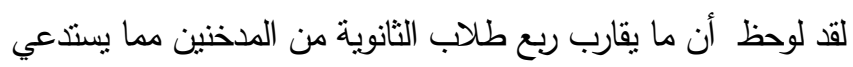
تخخلاً عاجلاً من الجهات المعنية لمكافحة هذه الآفة. 